\title{
PEMBUATAN BIOPLASTIK DARI PATI UBI KAYU BERPENGUAT NANO SERAT JERAMI DAN ZNO
}

\section{The Making of Bioplastic from Cassava Starch Reinforced by Nano Fiber Straw and ZnO}

\author{
Chairul Amni*, Marwan, dan Mariana \\ Jurusan Teknik Kimia, Fakultas Teknik, Universitas Syiah Kuala \\ Jln. Tgk.Syech Abdurrauf 7 Darussalam Banda Aceh 23111 \\ *e-mail: c_amni@yahoo.co.id.
}

Diterima: 5 Agustus 2015, revisi akhir: 3 Desember 2015 dan disetujui untuk diterbitkan: 5 Desember 2015

\begin{abstract}
ABSTRAK
Pembuatan film plastik biodegradable telah dilakukan dengan menggunakan pati ubi kayu yang berfungsi sebagai bahan baku utama dan bahan-bahan lain yaitu aquades yang berfungsi sebagai pelarut, serta nano serat jerami, $\mathrm{ZnO}$ dan campuran dari serat jerami dan $\mathrm{ZnO}$ yang berfungsi sebagai penguat bioplastik. Pati ubi kayu dipilih sebagai bahan baku pembuatan plastik karena selain mudah didapat dan harganya murah, penggunaannya juga masih sangat minim jika dibandingkan dengan tumbuhan lainnya yang merupakan bahan makanan pokok masyarakat, seperti beras, jagung, kentang, gandum, dan lain sebagainya. Penelitian ini bertujuan untuk membuat plastik yang dapat mengurangi dampak lingkungan dengan melihat pengaruh konsentrasi penguat yang digunakan terhadap sifat mekanik film, daya serap air, dan laju penguraian dari plastik tersebut. Penguat yang digunakan adalah serat jerami yang berukuran nano, $\mathrm{ZnO}$ dan campuran keduanya dengan konsentrasi $1 \%, 3 \%, 6 \%$, dan $9 \%$ dari masing-masing penguat. Pengujian sifat mekanik (kuat tarik dan elongasi) menggunakan Electronic System Universal Testing Machines, pengujian daya serap air dilakukan dengan cara merendam film tersebut di dalam air selama 24 jam, dan pengujian laju penguraian dilakukan dengan cara menguburkan film ke dalam tanah. Hasil penelitian menunjukkan nilai kuat tarik tertinggi diperoleh pada konsentrasi $9 \% \mathrm{ZnO}$ yaitu $0,32 \mathrm{kgf} / \mathrm{mm}^{2}$, sebaliknya persen elongasi tertinggi diperoleh pada konsentrasi $1 \%$ nano serat jerami yaitu $34 \%$. Daya serap air terendah yaitu $16 \%$ diperoleh pada konsentrasi $9 \% \mathrm{ZnO}$. Penyerapan air paling tinggi adalah $27,23 \%$ pada konsentrasi nano serat jerami $1 \%$ dan proses penguraian terjadi selama 18-27 hari.
\end{abstract}

\section{Kata Kunci: Biodegradable, pati ubi kayu, nano serat jerami, ZnO}

\section{ABSTRACT}

Production of biodegradable plastic film had been done using cassava starch which serves as a main raw material, distilled water as a solvent, as well as nano fiber straw, $\mathrm{ZnO}$, and a mixture of nano fiber straw and $\mathrm{ZnO}$ that function as a reinforcement of bioplastic. Cassava starch was chosen as the raw material for making plastics because of easy to obtain and inexpensive, moreover the use is still very low when compared to other plants that as staple food stuffs, such as rice, corn, potatoes, wheat, and so forth. This research was aimed to make plastics that can reduce the environmental impact by looking at the effect of reinforcing the concentration used for the mechanical properties of the film, water absorption, and the decomposition rate of the plastic. The reinforcer used was nano fibers straw, $\mathrm{ZnO}$, and a mixture of both with a concentration of $1 \%, 3 \%, 6 \%$, and $9 \%$ of each reinforcer. Testing of mechanical properties (tensile strength and elongation) used the Electronic System Universal Testing Machines, testing of water absorption was done by immersing the film in water for 24 hours, and testing of decomposition rate was done by burying the film into the ground. The results showed the highest tensile strength values was $0.32 \mathrm{kgf} / \mathrm{mm}^{2}$ obtained at a concentration of $9 \% \mathrm{ZnO}$, whereas the highest percent elongation was $34 \%$ obtained at a concentration of $1 \%$ nano-fiber straw. The lowest water absorption was $16 \%$ obtained at a concentration of $9 \% \mathrm{ZnO}$. The highest absorption of water was $27.23 \%$ obtained at a concentration of $1 \%$ nano-fiber straw and the decomposition process occured for 18-27 days.

\section{Keywords: Biodegradable, cassava starch, nano-fiber straw, ZnO}




\section{PENDAHULUAN}

Pencemaran lingkungan merupakan masalah yang sangat serius yang perlu perhatian seluruh lapisan masyaraka. Salah satunya adalah pencemaran yang disebabkan oleh limbah plastik. Plastik banyak digunakan dalam kehidupan seharihari karena memiliki sifat yang kuat, stabil dan ringan. Namun material plastik tersebut terbuat dari bahan-bahan yang tidak dapat diperbaharui dan tidak dapat diuraikan oleh mikroba, Untuk mengatasi hal tersebut maka material plastik dibuat dari bahanbahan alami yaitu pati.

Pati merupakan biopolimer karbohidrat yang dapat terdegradasi secara mudah di alam. Selain itu, sumber-sumber pati sangat mudah dan murah didapatkan sebagai bahan utama dalam proses sintesis plastik biodegradable. Untuk lingkup Indonesia pemanfaatan tapioka yang merupakan pati ubi kayu, merupakan pilihan yang baik, karena ubi kayu sumber utama pati, ketersediaannya melimpah dan sangat mudah diperbarui (renewable)(FernandezKim, 2004). Untuk memberikan ketahanan dan kekuatan mekanis pada pati, sejumlah pengisi (penguat) berupa bahan logam dan alami biasanya ditambahkan ke dalam matriks polimer (Yuli, 2010).

$\mathrm{ZnO}$ merupakan salah satu penguat logam yang sering digunakan karena $\mathrm{ZnO}$ adalah keramik piezoelektrik dan bersifat anti mikroba (Wang, 2007). Serat nano jerami merupakan limbah jerami padi bahan alami yang bisa bersifat penguat, sehingga dapat mengurangi kelembaban dan bisa membuat makanan lebih awet ataupun tahan lama (Junjun L, 2012). Dalam penelitian ini akan dilakukan pembuatan bioplastik yang merupakan plastik biodegradable dengan bahan dari pati ubi kayu, namun pati memiliki kekurangan antara lain kurang terhadap ketahanan air dan sifat mekaniknya (Ban, 2005).

Tujuan penelitian ini adalah untuk melihat karateristik plastik biodegradable dan pengaruh penambahan $\mathrm{ZnO}$ dan nano serat jerami sebagai bahan penguat.

\section{METODOLOGI PENELITIAN}

Alat dan bahan yang digunakan dalam penelitian ini, magnektic stirrel, gelas ukur, thermometer, neraca analitik, ball mill, SEM, alat kuat tarik, alumanium foil dan lain-lain. Bahan yang digunakan yaitu, pati kayu, nano serat jerami, ZnO, asam asetat, gliserol, akuades dan lain-lain.

Diagram proses pembuatan plastik biodegradable diperlihatkan pada Gambar 1.

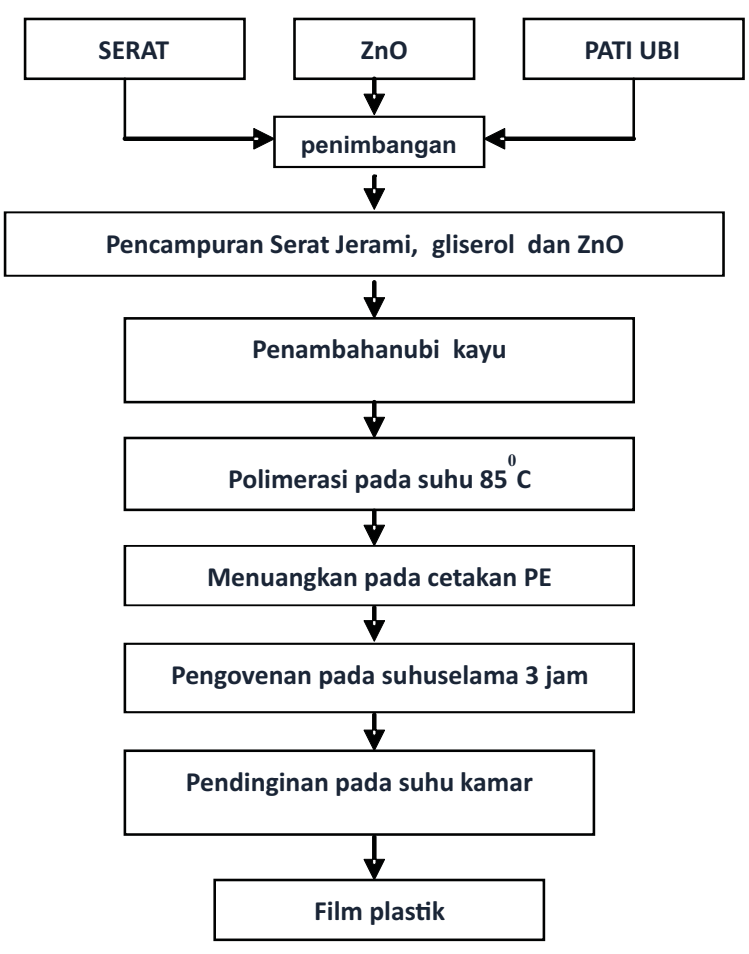

Gambar 1. Diagram proses pembuatan plastik biodegradble

Analisis deskriptif pada penelitian pembuatan plastik yang ramah lingkungan dilakukan untuk menjelaskan proses penelitian antara bahan alami dengan bahan kimia untuk menjadi plastik yang bersifat biodegradable yang memiliki sifat morfologi maupun mekanik yang baik dan ramah lingkungan. Pada rancangan penelitian ini terdiri dari perkerjaan utama untuk melihat ketahanan dan optimasi plastik yang ramah lingkungan. 
1. Variasi penguat $\mathrm{ZnO}$

Penelitian ini mengacu pada penelitian yang dilakukan oleh peneliti sebelumnya yaitu (Ahmad Ervan, 2012). Dimana konsentrasi penguat yang ditentukan oleh sifat mekanis bioplastik. Pada tahap ini penguatnya yaitu antara $\mathrm{ZnO}$ dengan konsentrasi $1 \%, 3 \%, 6 \%$, dan $9 \%$ dengan pemlastis gliserol $25 \%$ (dari 5 gram berat pati).

2. Pembuatan bioplastik konsentrasi penguat nanojerami

Untuk mencari konsentrasi penguat nano jerami yang optimum di tentukan melalui sifat mekanis bioplastik itu sendiri namun proses pembuatannya mengacu pada penelitian sebelumnya (Ryan, 2011) dengan konsentrasi $1 \%, 3 \%, 6 \%$, dan $9 \%$ dengan pemlastis gliserol $25 \%$ (dari 5 gram berat pati).

3. Pembuatan bioplastik dengan kombinasi nano jerami dan penguat $\mathrm{ZnO}$. Tahap ini bertujuan untuk mencari konsentrasi penguat yang optimum ditentukan melalui sifat mekanis bioplastik. Pada tahap ini penguatnya yaitu antara nano jerami dengan variasi konsentrasi $\mathrm{ZnO}$ $1 \%, 3 \%, 6 \%$, dan $9 \%$ dari (5 grpati).

Setelah selesai dengan proses pembuatan bioplastik yang ramah lingkungan disebut plastik biogreadable maka selanjutnya akan di uji karateristik yang meliputi kuat tarik dan elongasi, setelah itu di uji studi terhadap struktur morfologi dan fisiologi dengan menggunakan SEM (Scanning Electron Microscope), kemudian di uji daya serap air, dan yang terakhir Uji biodegradabilitas.

\section{HASIL DAN PEMBAHASAN}

Pembuatan plastik biodegradable dari pati ubi kayu dengan penambahan $\mathrm{ZnO}$ dan nano serat jerami pada penelitian ini hampir sama dengan plastik biodegradable yang dibuat dengan bahan baku pati lainya, namun demikian yang membedakan secara fisik adalah pada kecerahan warna terutama pada pelakuan penambahan nano serat jerami lebih bening dan lembut dipermukaan plastik bila dibandingkan dengan penambahan $\mathrm{ZnO}$ yang hasilnya lebih kasar dan berwarna suram, bioplastik dari hasil penelitian seperti Gambar 2.

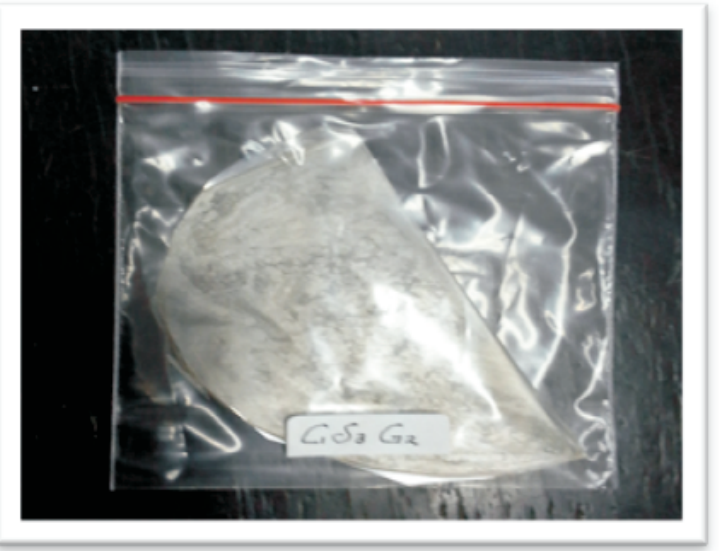

a. Nano serat jerami $1 \%$

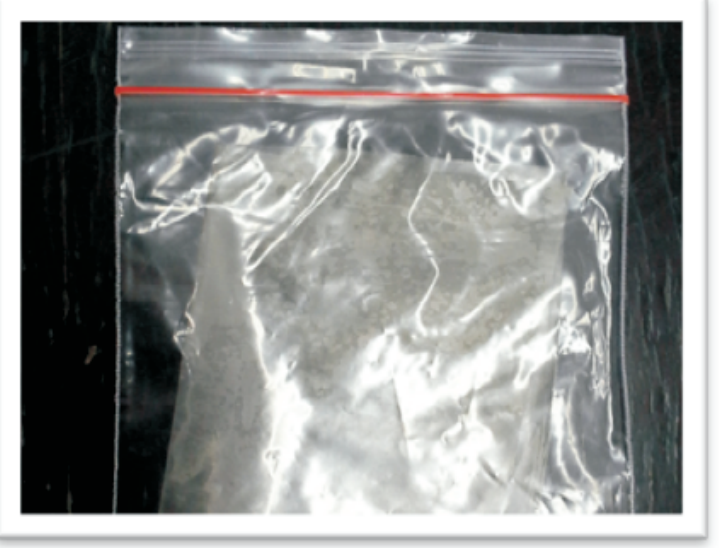

b. $\mathrm{ZnO} 1 \%$

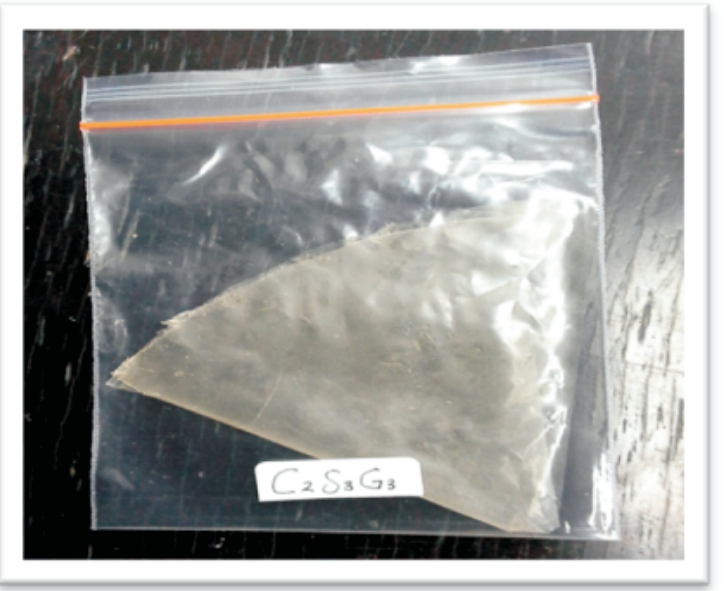

c. ZnO dan nano serat jaerami

Gambar 2. Gambar plastik biodegradable 


\section{Kuat Tarik (Tensile Strength)}

Kuat tarik (tensile strength) merupakan ukuran untuk kekuatan film secara spesifik, merupakan tarikan maksimum terakhir sebelum putus/sobek. Pengukuran ini untuk mengetahui besarnya gaya yang di perlukan untuk mencapai titik tarikan yang maksimum pada setiap luas permukaan film. Sifat tensile strength tergantung pada kosentrasi dan jenis bahan pembuat bioplastik terutama sifat kohesi stuktural. Kohesi stuktural adalah kemampuan polimer untuk menentukan kuat atau tiada melekur maupun ikatan antar rantai polimer (Fauzi, 2013).

Pengujian ini bertujuan untuk melihat perubahan yang terjadi pada kekuatan mekanik plastik. Pengujian kuat tarik dilakukan dengan menggunakan Electronic System Universal Testing Machines berdasarkan standar ASTM D882 91. Untuk mengetahui hasil pengujian kuat tarik dapat dilihat pada Gambar 3.

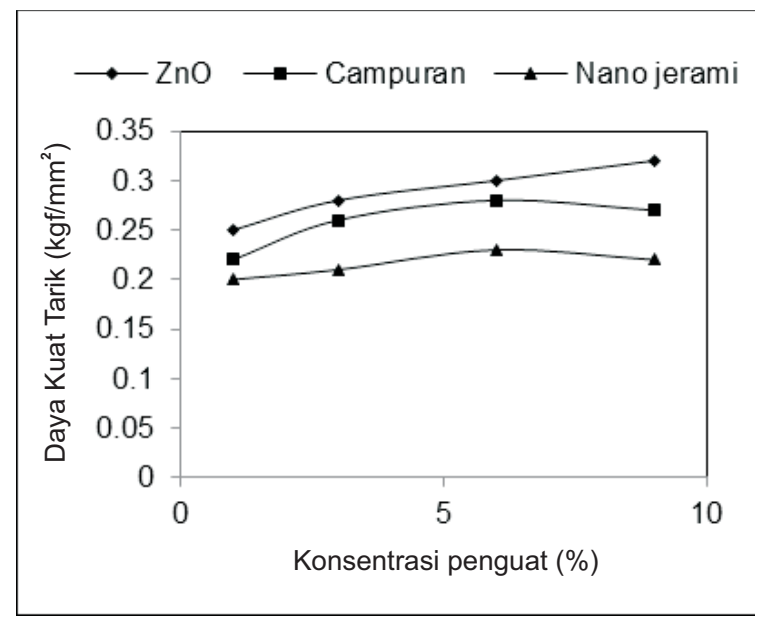

Gambar 3. Pengaruh konsentrasi penguat terhadap kuat tarik bioplastik.

Dari Gambar 3.dapat dilihat bahwa penambahan komposisi bahan sangat mempengaruhi kuat tarik dari film plastik tersebut. Nilai kuat tarik yang paling tinggi dihasilkan pada penambahan ZnO 9\% yaitu $0,32 \mathrm{kgf} / \mathrm{mm}^{2}$, pada penambahan campuran antara keduanya yang paling tinggi kuat tariknya adalah dengan konsentrasi nano serat jerami dan $\mathrm{ZnO} 6 \%$ yaitu $0,28 \mathrm{kgf} / \mathrm{mm}^{2}$, kuat tarik pada komposisi nano serat jerami yang tertinggi pada kosentrasi $6 \%$ yaitu 0,23 $\mathrm{kgf} / \mathrm{mm}^{2}$. Pada gambar ini juga dapat dilihat bahwa semakin banyak ditambah bahan penguat $\mathrm{ZnO}$, maka nilai kuat tarik bioplastik yang dihasilkan semakin tinggi. Hal ini disebabkan karena semakin banyak bahan penguat $\mathrm{ZnO}$ akan mempengaruhi struktur dari bioplastik tersebut, namun nilai kuat tarik penguat jerami maupun campuran pada $9 \%$ mengalami penurunan.

Hasil penelitian untuk jenis penguat bioplastik menunjukkan bahwa bioplastik yang menggunakan penguat $\mathrm{ZnO}$ menghasilkan nilai kuat tarik lebih besar dibandingkan dengan penguat nano serat jerami dan campuran antara $\mathrm{ZnO}$ dan nano serat jerami. Hal ini dikarenakan gugusgugus pada $\mathrm{ZnO}$ akan menangkap elektron dari gugus hidroksil $(\mathrm{OH})$ pada polimer sehingga gugus tersebut dapat berikatan. Kuat tarik dari film plastik sangat dipengaruhi oleh kandungan penguat bioplastik yang ditambahkan. karena peningkatan konsentrasi penguat akan menaikkan ikatan hidrogen dalam film sehingga akan memperbesar kemampuan sehingga kuat tarik dari film akan semakin tinggi.

\section{Elongasi}

Elongasi merupakan perubahan panjang maksimal film sebelum terputus, Semakin tinggi nilai elongasi dari suatu plastik maka semakin tidak mejamin kualitas dari plastik tersebut. Persen elongasi ini juga dipengaruhi oleh kandungan $\mathrm{ZnO}$, nano serat jerami, dan campuran antara keduanya. Elongasi adalah sifat mekanik yang erat hubungannya dengan sifat fisik bioplastik, hal ini menunjukan perubahan panjang bioplastik saat maksimum dengan memperoleh gaya tarik sampai bioplastik putus, nilai elongasi menunjukan kemampuan bioplastik untuk memanjang, sifat ini tergantung pada jenis bahan pembentukan bioplastik yang mempengaruhi sifat kohesi struktur bioplastik. Gambar 4 adalah hasil elongasi untuk penguat $\mathrm{ZnO}$, nano serat jerami dan campuran keduanya. 


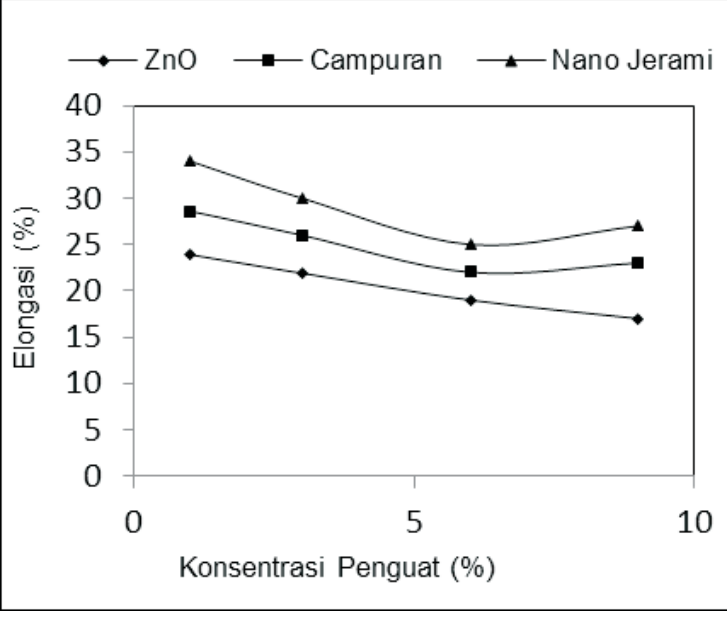

Gambar4. Pengaruh jenis penguat terhadap elongasi bioplastik.

Hasil dari analisis menunjukan bahwa konsentrasi penguat sangat berpengaruh terhadap elongasi bioplastik. Dari Gambar 4 dapat dilihat bahwa nilai elongasi pada masing-masing perlakuan memiliki kemampuan untuk memanjang. Elongasi yang paling tinggi pada $1 \%$ nano serat jerami yaitu sebesar $34 \%$ sedangkan yang paling kecil elongasinya terdapat pada konsentrasi $9 \%$ ZnO yaitu sebesar $17 \%$. Hal ini disebabkan oleh sedikit penguat yang ditambahkan sehingga menurunnya jarak ikatan melekul dan dapat mengurangi ikatan hidrogen internal hingga melemahnya gaya tarik pada rantai polimer sebelum putus. Dapat dilihat bahwa kosentrasi penguat berbanding dengan persen elongasi bioplastik, hal ini mungkin terjadi karena waktu pengeringan yang terlalu lama, suhu pengeringan yang tidak konstan, bahan yang kurang homogen ataupun terlalu lama tersimpan.

\section{Uji Daya Serap Air}

Salah satu sifat dari plastik konvensional adalah kedap terhadap air. Daya serap air adalah banyaknya air yang diserap oleh film plastik dalam persen setelah contoh uji direndam dalam air pada suhu kamar selama 24 jam. Air tersebut mengisi ruang-ruang kosong dalam film plastik tersebut, Dari Gambar 5 menunjukan hasil uji daya serap air untuk bioplastik dengan menggunakan penguat $\mathrm{ZnO}$, nano serat jerami, dan kombinasi $\mathrm{ZnO}$ dan nano serat jerami, semakin rendah persen daya serap air yang didapat maka semakin baik kualitas dari plastik tersebut. Nilai daya serap air hasil penelitian berkisar antara 16\%-27,23\%.

Peningkatan kadar penguat yang ditambahkan pada bioplastik akan menyebabkan daya serap air pada bioplastik semakin kecil. Hal ini terjadi karena selain bioplastik dari pati sendiri yang memang bersifat hidrofilik, plasticizer juga bersifat hidrofilik sehinga daya serap air dari lingkungan ke permukaan sampel bioplastik.

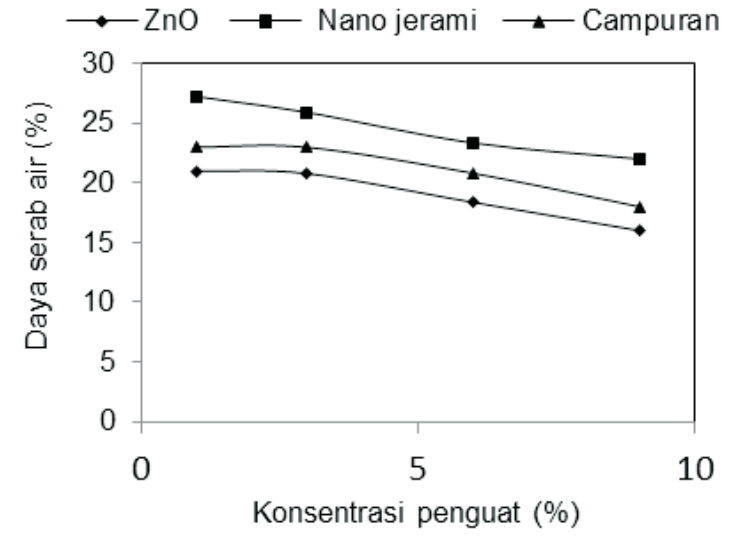

Gambar5. Pengaruh komposisi bahan penguat terhadap daya serap air

Gambar 5. menunjukkan perubahan daya serap air dari film plastik dengan penambahan bahan penguat yaitu $\mathrm{ZnO}$, nano serat jerami dan campuran antara keduanya maupun plasticizer sebesar 1,25 $\mathrm{ml}$. Penambahan konsentrasi penguat sangat mempengaruhi daya serap air karena sifat dari bahan penguat tersebut besifat hidrofilik, hal ini disebabkan nilai daya serap air dengan penguat logam $\mathrm{ZnO}$ lebih kecil dibandingkan dengan penguat alami yaitu nano serat jerami karena penguat logam memiliki resistansi yang baik dari pada penguat alami yang tersusun dari polisakarida.

\section{Uji Penguraian (Degradability)}

Bioplastik dari ubi kayu dengan penambahan penguat seperti $\mathrm{ZnO}$ dan nano serat jerami diuji sifat biodegradablenya dengan menggunakan tanah. Bakteri- 
bakteri yang ada didalam tanah akan menguraikan plastik yang sudah ditanam sehingga memutus rantai-rantai polimer menjadi monomer-monomernya melalui enzim yang dihasilkan dari bakteri tersebut. Proses ini akan menghasilkan senyawasenyawa organik berupa asam amino, asam laktat, gula, alkohol, vitamin, protein dan senyawa organik lainya yang aman terhadap lingkungan sekitar, kemampuan bioplastik degradasi karena pendeknya rantai ikatan yang dimiliki semakin rendah berat melekul maka polimer semakin mudah terdegradasi (Jannah, 2014).

Analisa biodegradasi bioplastik dilakukan melalui pengamatan film secara visual. Hasil uji biodegradasi dari bioplastik ubi kayu dengan penambahan penguat baik itu ZnO maupun nano serat jerami ditunjukan pada Gambar 6, 7, dan 8. Proses uji biodegradable ini diperlukan untuk mempelajari tingkat biodegradability film plastik yang dihasilkan kaitannya dengan pengaruh mikroba pengurai, kelembaban tanah dan suhu bahkan faktor kimia/fisika lain. Secara kimiawi, film plastik yang dihasilkan jelas bersifat biodegradable, hal itu disebabkan oleh bahan baku yang digunakan adalah bahan baku organik dan alami yang mudah berinteraksi dengan air dan mikroorganisme lain bahkan sensitif terhadap pengaruh fisik/kimia lingkungan.

Faktor-faktor kelembaban tanah dan suhu yang juga turut mempengaruhi namun tidak diuji dalam penelitian ini. Sampel tanah yang dijadikan media adalah tanah humus yang berasal dari sisa pembakaran sampah yang kaya akan bakteri pengurai. Jamur dan arga ini akan mendegradasi bioplastik yang mengandung pati dengan cara memutus rantai polimer menjadi monomermonomernya melaui enzim yang dihasilkan dari bakteri tersebut. Proses ini akan menghasilkan senyawa-senyawa organik berupa asam amino, asam laktat, gula, alkohol, vitamin, protein dan senyawa organik lainnya yang aman terhadap lingkungan (Jannah, 2014).

Dari hasil pengujian film plastik yang dihasilkan jelas bersifat biodegradable, dimana rata-rata film plastik terurai pada hari ke-15. Hal ini sesuai dengan standar plastik biodegradable yang harus terurai kurang dari 180 hari (ASTM D 6400 dan EN 13432).

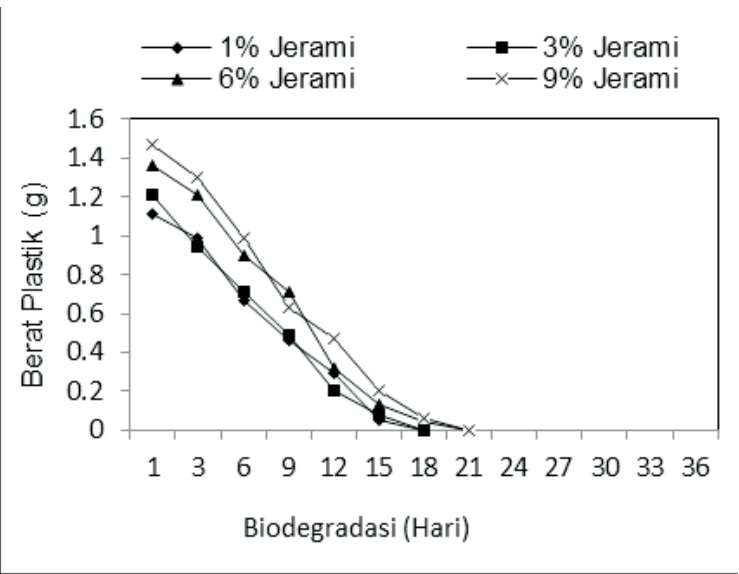

Gambar 6. Grafik penguraian plastik dengan penguat nano jerami

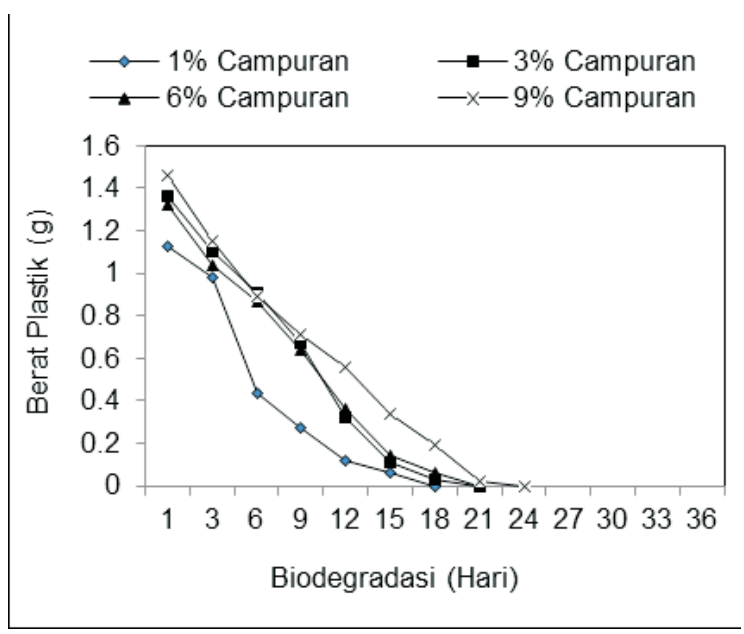

Gambar7. Grafik penguraian plastik dengan penguat campuran antara ZnO dan nano jerami

Gambar 6, 7, dan 8 menunjukkan proses uji biodegradable yang terjadi, dimana setelah dilakukan penguburan selama 3 hari setelah ditanam, hasil pengamatan menunjukkan bahwa film plastik telah terdekomposisi/terdegradasi secara alamiah didalam tanah walaupun masih tersisa banyak, yang diakibatkan oleh banyak faktor, diantaranya adalah faktor mikroorganisme pengurai, kelembaban tanah dan kadar air tanah. Alasan utama membuat kemasan plastik berbahan dasar 
biopolimer adalah sifat alamiahnya yang dapat hancur atau terdegradasi dengan mudah.

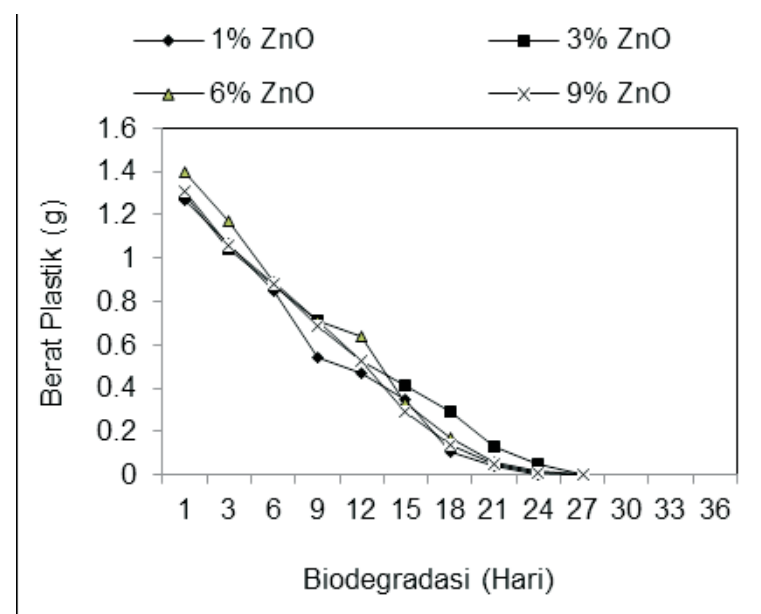

Gambar8. Grafik penguraian plastik dengan penguat $\mathrm{ZnO}$

Pada hari terakhir setelah dilakukan penggalian lagi, ternyata sisa-sisa film plastik tersebut sudah bersih/terdegradasi sempurna, plastik yang paling cepat terurai oleh mikroorganisme adalah pada kosentrasi penguat $1 \%$ dan $3 \%$ nano serat jerami dengan masa degradasi 18 hari dan yang paling lama terdegradasi oleh tanah pada kosentrasi $3 \%, 6 \%$ dan $9 \% \mathrm{ZnO}$ dengan masa degradasi 27 hari. Kondisi tanah yang digunakan untuk proses penguburan adalah lembab dan banyak mengandung air serta dimungkinkan banyak terdapat mikroba pengurai yang berperan.

Karakter biodegradabilitas telah teruji secara praktis bahwa film plastik yang dihasilkan ternyata dapat dengan mudah diuraikan dalam tanah secara biologis maupun kimiawi dan tentunya aman bagi lingkungan. Secara kimiawi, film plastik yang dihasilkan jelas bersifat biodegradable, hal ini disebabkan oleh bahan baku yang digunakan adalah bahan baku organik dan alamiah yang mudah berinteraksi dengan air dan mikroorganisme lain.

\section{Uji SEM Bioplastik}

Analisis morfologi yang dilakukan di laboratorium material dengan menggunakan alat HITACHI Tabletop SEM TM-3000 bertujuan untuk menentukan homogenitas.

\section{a. $3 \%$ Nano Jerami}

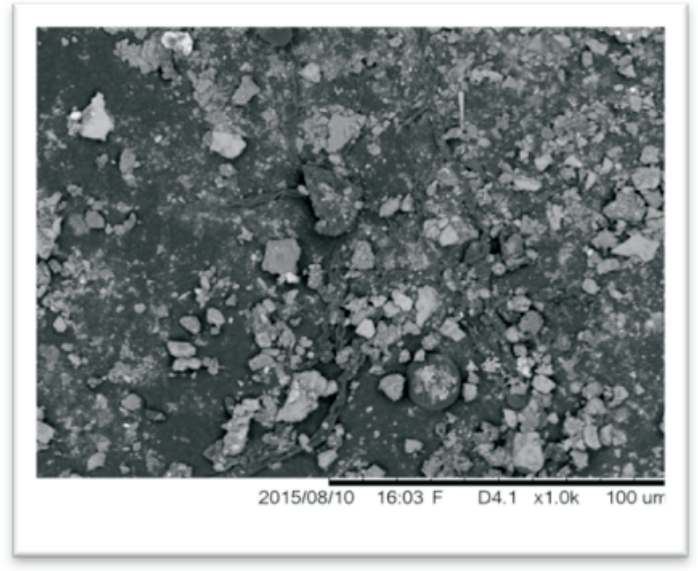

b. $3 \%$ Campuran antara keduanya

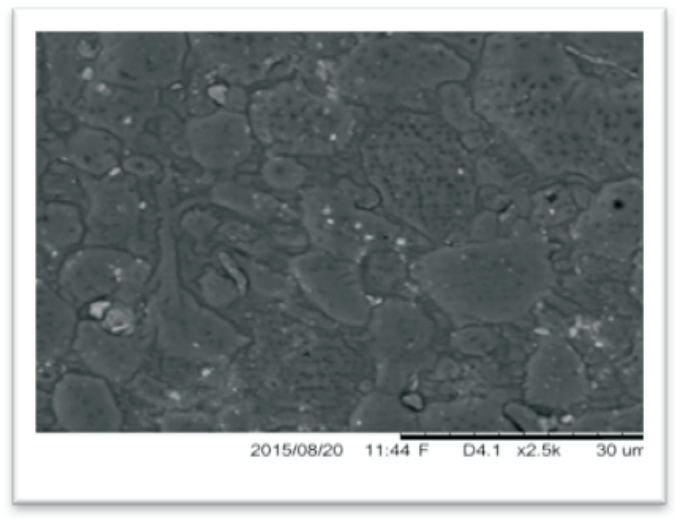

c. $3 \% \mathrm{ZnO}$

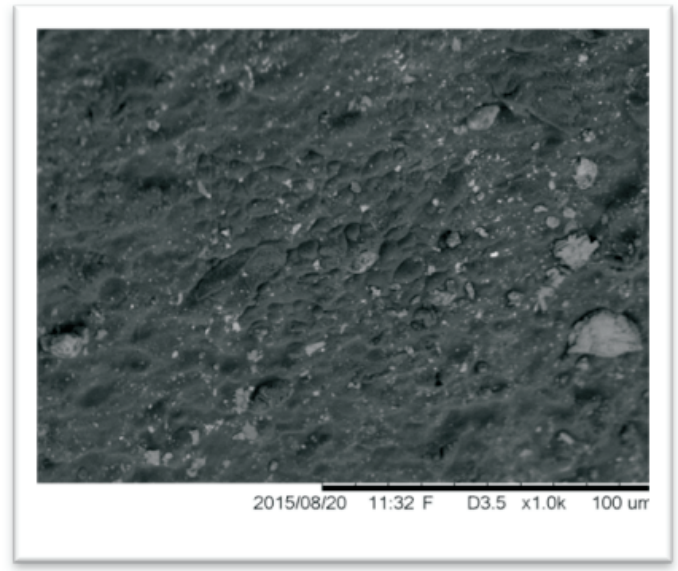

Gambar9. Hasil pengujian SEM pada Penguat dengan konsentrasi a. $3 \%$ Nano Serat Jerami, b. 3\% campuran kedunya, dan c. $3 \%$ $\mathrm{ZnO}$. 
Dari pengamatan struktur mikron menggunakan SEM untuk sampel bioplastik seperti yang disajikan pada gambar diatas tampak bahwa partikel-pertikelnya tidak saling berikatan satu dengan yang lain baik itu di nano serat jerami mupun di campuran. Berbanding terbalik dengan $\mathrm{ZnO}$, terlihat bahwa $\mathrm{ZnO}$ larut dalam pati dan tergolong cukup rapat sehingga air yang diserap cukup rendah dibandingkan bioplastik lainnya, tetapi terdapat pori yang tidak merata yang disebabkan oleh pengadukan yang belum sempurna dan struktur morfologi film yang dihasilkan tidak homogen yang disebabkan oleh pencampuran yang kurang sempurna dan adanya nano serat jerami yang tidak larut dalam pelarut organik.

Pada permukaan bioplastik yang dihasilkan terlihat adanya gelembunggelembung udara. Pembentukan rongga udara disebabkan oleh pengadukan dan proses pencetakan bioplastik yang mempengaruhi struktur permukaan bioplastik yang dihasilkan. Semakin baik proses pencetakannya maka uap air yang terkandung dalam bahan akan cepat menguap, sehingga dalam proses penguapan air tersebut partikel-partikel bahan akan bergerak ke atas dan menyebabkan lapisan antar sel menyatu (Utomo, 2013). Pada foto SEM tampak pula bahwa masih terdapatnya struktur granula pati didalamnya meskipun sudah tidak utuh. Besarnya ukuran granula yang masih bisa diamati memiliki diameter $30 \mu \mathrm{m}$. Pati yang berasal dari biji, umbi, akar, dan batang tanaman memiliki diameter granula yang bervariasi antara 2-100 $\mu \mathrm{m}$.

\section{KESIMPULAN}

Nilai kuat tarik dapat dilihat, bahwa penambahan komposisi bahan sangat mempengaruhi kuat tarik dari film plastik tersebut. Nilai kuat tarik yang paling tinggi dihasilkan pada penambahan $\mathrm{ZnO}$ pada kosentrasi $9 \%$ yaitu $0,32 \mathrm{kgf} / \mathrm{mm}^{2}$. Daya kuat tarik yang paling kecil pada nano serat jerami dengan konsentrasi $1 \%$ yaitu dengan nilai $0,2 \mathrm{kgf} / \mathrm{mm}^{2}$.

Elongasi yang paling tinggi jatuh pada $1 \%$ nano serat jerami sebesar $34 \%$ elogansinya, sedangkan yang paling kecil elongansinya terdapat pada konsentrasi $9 \%$ $\mathrm{ZnO}$ yaitu sebesar $17 \%$. Nilai daya serap air dari hasil penelitian berkisar antara kosentrasi yang paling rendah $9 \% \quad \mathrm{ZnO}$ dengan hasil $16 \%$ penyerapan air, hingga kosentrasi yang paling tinggi yaitu $1 \%$ Nano serat jerami dengan hasil penyerapan air $27,23 \%$. Proses degradasi film plastik terjadi selama 18-27 hari. Hasil analisa SEM pada permukaan plastik biodegradable terlihat bahwa nano serat jerami tidak larut dalam pati, sehingga jelas nampak nano jerami kecil-kecil sedangkan $\mathrm{ZnO}$ larut dalam pembuatan plastik sehingga ketahanan plastik tersebut tampak jelas.

\section{Saran}

Penulis menyarankan pada penelitian lebih lanjut agar dapat menvariasikan bahan aditif penguat lainya dengan kombinasi yang berbeda untuk memperbaiki dan meningkatkan sifat fisik maupun mekanik film plastik.

\section{DAFTAR PUSTAKA}

Ahmad, E. 2012. Sintesis bioplastik dari pati ubi jalar menggunakan penguat logam $\mathrm{ZnO}$ dan penguat alami khitosan.

Ban, W. 2005. Improving the physical and chemical functionally of starch-derive films with biopolymers. Journal of Applied Polymer Science, 10,118-129.

Fauzi, A., Zulisma, A., Hamidah, H. 2013. Pengaruh waktu simpan film plastik biodegradable dari kulit pati singkong terhadap sifat mekeniknya, 11-15.

Fernandes-Kim. 2004. Physicochemical and functional properties of crawfish chitosan as affected by different processing protocols, a thesis in Departement of Food Science, Seoul National University.

Jannah, R., Gusnedi. 2014. Analisa penambahan gula jagung terhadap kateristik dan degradasi plastik biodegradasi air pati ubi kayu, 81-88.

Junjun, L., Chanjuan, J., Chunxia He. 2012. Rice straw and corn starch. Biodegradable Composites. 83-88. 
Ryan, A. 2011. Pemafaatan pati ubi garut untuk pembuatan plastik biodegradable.

Utomo. 2013. Pengaruh suhu dan lama pengeringan terhadap karateristik fisikokimiawi plastic biodegradable dari komposit lidah buaya (aloe Vera).
Wang, Z., L. 2007. Toward self-powered nanosystems: From nanogene-rators to nanopiezotronics. Advanced Functional Materials, 18 (DOI:10.1002/adfm.200800541), 5533567

Yuli, D. 2010. Studi pembuatan dan karakteristik sifat mekanik dan hidrofobisitas bioplastik dari pati sorgum. 